\title{
New tick records in Rondônia, Western Brazilian Amazon
}

\author{
Novos relatos de carrapatos em Rondônia, Amazônia ocidental brasileira \\ Marcelo Bahia Labruna ${ }^{1 *}$; Fábio Silva Barbieri²; Thiago Fernandes Martins ${ }^{1}$; \\ Luciana Gatto Brito ${ }^{2}$; Francisco Dimas Sales Ribeiro ${ }^{3}$

\begin{abstract}
${ }^{1}$ Department of Preventive Veterinary Medicine and Animal Health, Faculty of Veterinary, University of São Paulo - USP, CNPq fellowship

${ }^{2}$ Center for Agroforestry Research of Rondônia, EMBRAPA Rondônia

${ }^{3}$ Regional Office of IBAMA
\end{abstract}

Received April 5, 2010

Accepted April 26, 2010

\begin{abstract}
In the present study, we provide new tick records from Vilhena Municipality, in the Southeast of the State of Rondônia, Northern Brazil. Ticks collected from a capybara, Hydrochoerus hydrochaeris (Linnaeus), were identified as Amblyomma romitii Tonelli-Rondelli (1 female), and Amblyomma sp. (1 larva). Ticks collected from a harpy eagle, Harpia harpyja (Linnaeus), were identified as Amblyomma cajennense (Fabricius) (16 nymphs) and Haemaphysalis juxtakochi Cooley (1 nymph). Ticks collected from a yellow-footed tortoise, Chelonoidis denticulada (Linnaeus), were identified as Amblyomma rotundatum Koch (10 females, 2 nymphs), and Amblyomma sp. (2 larvae). The present record of $A$. romitii is the first in the State of Rondônia, and represents the southernmost record for this tick species, indicating that its distribution area is much larger than currently recognized. Although both $A$. cajennense and $H$. juxtakochi have been reported parasitizing various bird species, we provide the first tick records on a harpy eagle. A. rotundatum is widespread in the State of Rondônia, and has been previously reported on the yellow-footed tortoise. The present records increase the tick fauna of Rondônia to 26 species.
\end{abstract}

Keywords: Amblyomma, Haemaphysalis, Harpia, capybara, tortoise.

\section{Resumo}

O presente estudo relata novos achados de carrapatos provenientes do Município de Vilhena, Sudeste do Estado de Rondônia, na regiáo Norte do Brasil. Carrapatos colhidos de uma capivara, Hydrochoerus hydrochaeris (Linnaeus), foram identificados como Amblyomma romitii Tonelli-Rondelli (1 fêmea) e Amblyomma sp. (1 larva). Carrapatos colhidos de uma águia harpia, Harpia harpyja (Linnaeus), foram identificados como Amblyomma cajennense (Fabricius) (16 ninfas) e Haemaphysalis juxtakochi Cooley (1 ninfa). Carrapatos colhidos de um jabuti, Chelonoidis denticulada (Linnaeus), foram identificados como Amblyomma rotundatum Koch (10 fêmeas, 2 ninfas) e Amblyomma sp. (2 larvas). O presente achado de $A$. romitii é o primeiro no Estado de Rondônia, representando o achado mais meridional desta espécie de carrapato, indicando que sua distribuiçấo geográfica é mais ampla do que se supunha. Embora $A$. cajennense e $H$. juxtakochi têm sido relatados parasitando várias espécies de aves, o presente relato em harpia é o primeiro registro de carrapatos nesta espécie de hospedeiro. A. rotundatum ocorre amplamente no Estado de Rondônia e tem sido previamente relatado parasitando jabutis. Estes registros ampliam a fauna de carrapatos de Rondônia para 26 espécies.

Palavras-chave: Amblyomma, Haemaphysalis, Harpia, capivara, jabuti.

The tick fauna of the world is currently represented by 879 valid tick species into the families Ixodidae (692 species), Argasidae (186), and Nuttalliellidae (1 specie) (NAVA et al., 2009). In Brazil, an updated checklist reported 61 species in nine genera, being 44 Ixodidae species and 17 Argasidae

\footnotetext{
*Corresponding author: Marcelo Bahia Labruna

Departamento de Medicina Veterinária Preventiva e Saúde Animal,

Faculdade de Medicina Veterinária e Zootecnia, Universidade de São Paulo - USP,

Av. Prof. Orlando Marques de Paiva 87, CEP 05508-270,

Cidade Universitária, São Paulo - SP, Brazil;

e-mail: labruna@usp.br
}

species (DANTAS-TORRES et al., 2009). An extensive study (LABRUNA et al., 2005) reported 7,441 Ixodidae specimens collected from 2000 to 2005 in different parts of the State of Rondônia, Western Amazon, Brazil. These Ixodidae ticks encompassed 22 different species of the genera Amblyomma (16 species), Ixodes (2), Haemaphysalis (1), Dermacentor (1), and Rhipicephalus (2). In this later genus, the species Rhipicephalus (Boophilus) microplus was reported as Boophilus microplus. Regarding Argasidae ticks, recent studies reported for the first time three tick species in the State of Rondônia, two Antricola and one Carios species (LABRUNA et al., 2008). Therefore, the current tick 
fauna of Rondônia is composed by 25 species, which represent $41 \%$ of the Brazilian tick fauna. This number is remarkable if one considers that Rondônia represents only $2.8 \%$ of the Brazilian land area.

In the present study, we provide new tick records for the State of Rondônia. All ticks were collected from hosts hit by car in the BR364 road within the Vilhena Municipality $\left(12^{\circ} 72^{\prime} \mathrm{S}\right.$ and $\left.60^{\circ} 26^{\prime} \mathrm{W}\right)$, in the Southeast of the State. These hosts encompassed one capybara, Hydrochoerus hydrochaeris (Linnaeus), examined in 8 April 2009; one harpy eagle, Harpia harpyja (Linnaeus), examined in 15 September 2009; and one yellow-footed tortoise, Chelonoidis denticulada (Linnaeus), examined in January 2009. The ticks were collected and immediately preserved in $70 \%$ ethanol. Taxonomic identifications were performed following Barros-Battesti et al. (2006) for adult and larval ticks, Cooley (1946) and Kohls (1960) for a Haemaphysalis nymph, and Martins et al. (2010) for Amblyomma nymphs.

Ticks collected from capybara were identified as Amblyomma romitii Tonelli-Rondelli (1 female), and Amblyomma sp. (1 larva). Ticks collected from harpy eagle were identified as Amblyomma cajennense (Fabricius) (16 nymphs), and Haemaphysalis juxtakochi Cooley (1 nymph). Ticks collected from yellow-footed tortoise were identified as Amblyomma rotundatum Koch (10 females, 2 nymphs), and Amblyomma sp. (2 larvae). These ticks have been deposited in the tick collection "Coleção Nacional de Carrapatos" (CNC) of the Faculdade de Medicina Veterinária e Zootecnia of the University of São Paulo (accession numbers CNC-1534-1536).
The taxon $A$. romitii was recently revalidated and redescribed (BARROS-BATTESTI et al., 2007). Its current distribution encompasses the Guyanas (French, British, and Surinam), Venezuela, and the State of Para (Eastern Brazilian Amazon), where it typically feeds on capybaras (JONES et al., 1972; BARROS-BATTESTI et al., 2007). The present record is the first in the State of Rondônia, and represents the southernmost record for $A$. romitii, indicating that its distribution area is much larger than currently recognized. According to Barros-Battetsi et al. (2007), the most remarkable morphological features of the $A$. romitii female are the presence of dense white pilosity on alloscutum, eyes bulging laterally beyond the contour of the scutum, hypostome dentition varying from $4 / 4$ to $6 / 6$, and large spiracular plates with festooned margins. The $A$. romitii collected in the present study had all these features. Its dense white pilosity on alloscutum and a hypostome dentition 5/5 are illustrated in Figure 1.

To the best of our knowledge, our tick record on a harpy eagle represents the first on this rare bird species. Both $A$. cajennense and H. juxtakochi have been reported parasitizing various other bird species (BELDOMENICO et al., 2003; VENZAL et al., 2005; LABRUNA et al., 2007; OGRZEWALSKA et al., 2009; 2010). The species $A$. rotundatum is widespread in the State of Rondônia and other Brazilian States, where it feeds primarily on toads and snakes (LABRUNA et al., 2005; BARROS-BATTESTI et al., 2006; DANTAS-TORRES et al., 2008); however, this tick has been previously reported on the yellow-footed tortoise (DANTAS-TORRES et al., 2010). Finally, the present records increase the tick fauna of Rondônia to 26 species.
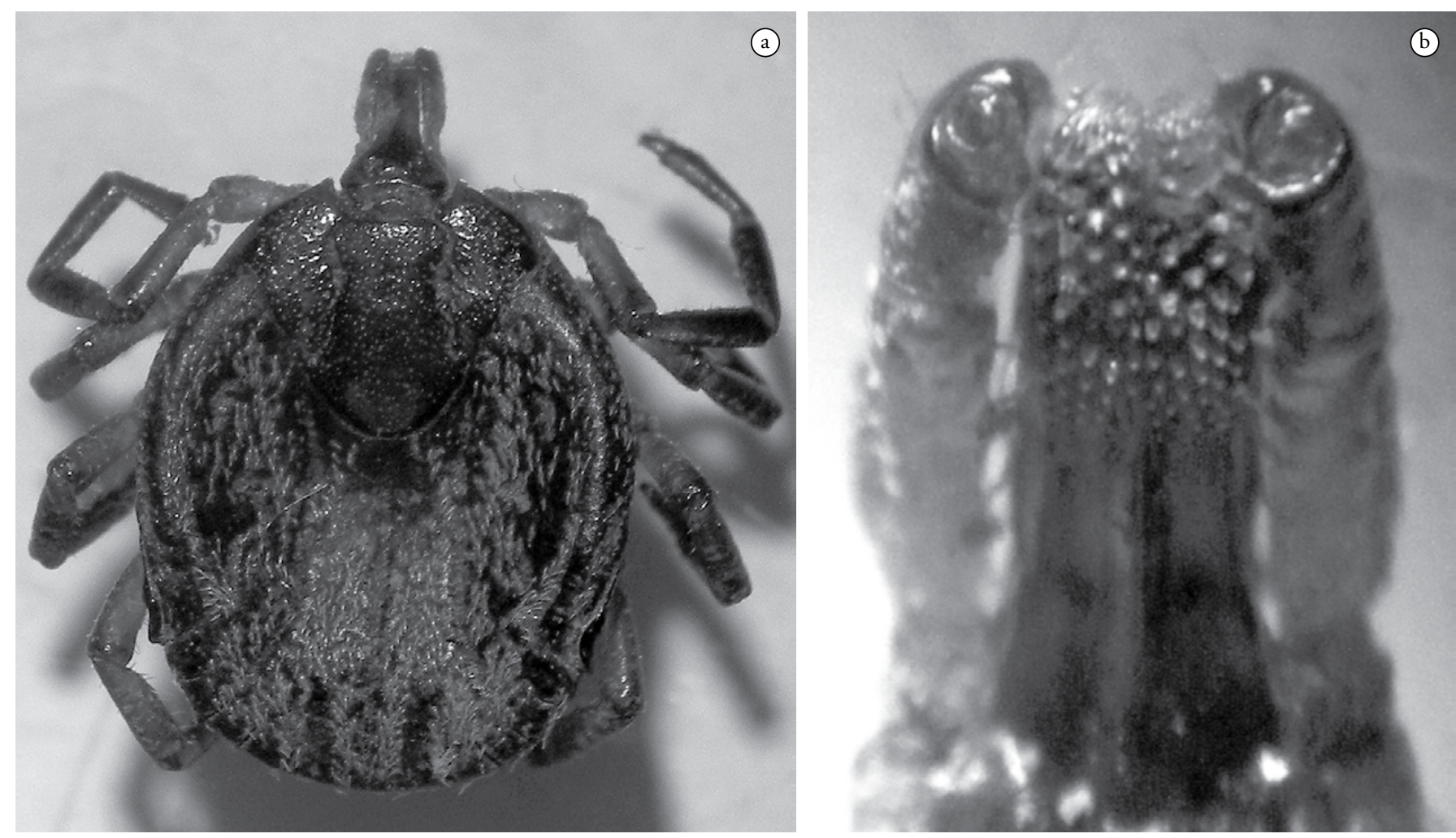

Figure 1. Amblyomma romitii female. a) Dorsal view. Note dense white pilosity on alloscutum. b) Hypostome. Note dentition $5 / 5$. 


\section{Acknowledgments}

Thanks to Alberto A. Guglielmone (INTA Rafaela, Argentina) for his technical support on part of this work. This work received financial support by the Conselho Nacional de Desenvolvimento Científico e Tecnológico (CNPq).

\section{References}

BARROS-BATTESTI, D. M.; ARZUA, M.; BECHARA, G. H. Carrapatos de importância médico-veterinária da Regiáo Neotropical: Um guia ilustrado para identificaçáo de espécies. São Paulo: Vox/ International Consortium on Ticks and Tick-borne Diseases/Butantan, 2006. 223 p.

BARROS-BATTESTI, D. M. et al. Validation and redescription of Amblyomma romitii Tonelli-Rondelli, 1939 (Acari: Ixodidae). Systematic Parasitology, v. 68, n. 2, p. 79-86, 2007.

BELDOMENICO, P. M. et al. Ixodid ticks (Acari: Ixodidae) present at Parque Nacional El Rey, Argentina. Neotropical Entomology, v. 32, n. 2, p. 273-277, 2003.

COOLEY, R. A. The genera Boophilus, Rhipicephalus and Haemaphysalis (Ixodidae) of the New World. Washington D.C.: National Institute of Health, 1946. 54 p.

DANTAS-TORRES, F. et al. Ticks infesting amphibians and reptiles in Pernambuco, Northeastern Brazil. Revista Brasileira de Parasitologia Veterinária, v. 17, n. 4, p. 218-221, 2008.

DANTAS-TORRES, F.; ONOFRIO, V. C.; BARROS-BATTESTI, D. M. The ticks (Acari: Ixodida: Argasidae, Ixodidae) of Brazil. Systematic and Applied Acarology, v. 14, p. 30-46, 2009.

DANTAS-TORRES, F. et al. Ticks on captive and free-living wild animals in northeastern Brazil. Experimental and Applied Acarology, v. 50, n. 2, p. 181-189, 2010.
JONES, E. K. et al. The ticks of Venezuela (Acarina: Ixodoidea) with a key to the species of Amblyomma in the Western Hemisphere. Brigham Young University Science Bulletin, Biological Series, v. 17, p. 1-40, 1972.

KOHLS, G. M. Records and new synonymy of New World Haemaphysalis ticks, with descriptions of the nymph and larva of $H$. juxtakochi Cooley. Journal of Parasitology, v. 46, n. 3, p. 355-361, 1960.

LABRUNA, M. B. et al. Ticks (Acari: Ixodidae) from the state of Rondônia, western Amazon, Brazil. Systematic and Applied Acarology, v. 10 , p. 17-32, 2005.

LABRUNA, M. B. et al. Ticks collected on birds in the state of São Paulo, Brazil. Experimental and Applied Acarology, v. 43, n. 2, p. 147-160, 2007.

LABRUNA, M. B. et al. New reports of Antricola guglielmonei and Antricola delacruzi in Brazil, and a description of a new argasid species (Acari). Journal of Parasitology, v. 94, n. 4, p. 788-792, 2008.

MARTINS, T. F. et al. Nymphs of the genus Amblyomma (Acari: Ixodidae) of Brazil: descriptions, redescriptions, and identification key. Ticks and Tick-borne Diseases, v. 1, n. 2, p. 75-99, 2010. DOI: $10.1016 /$ j.ttbdis.2010.03.002.

NAVA, S.; GUGLIELMONE, A. A.; MANGOLD, A. J. An overview of systematics and evolution of ticks. Frontiers in Biosciences, v. 14, p. 2857-2877, 2009.

OGRZEWALSKA, M. et al. Ticks (Acari: Ixodidae) infesting birds in an Atlantic rain forest region of Brazil. Journal of Medical Entomology, v. 46, n. 5, p. 1225-1229, 2009.

OGRZEWALSKA, M.; UEZU, A.; LABRUNA, M. B. Ticks (Acari: Ixodidae) infesting wild birds in the eastern Amazon, northern Brazil, with notes on rickettsial infection in ticks. Parasitology Research, v. 106, n. 4, p. 809-816, 2010.

VENZAL, J. M. et al. A collection of ticks (Ixodidae) from wild birds in Uruguay. Experimental and Applied Acarology, v. 36, n. 4, p. 325-331, 2005. 